\title{
Ecosystem Modifications (1956-2014) in Lake Victoria (East Africa): A Review
}

\author{
Moshe Gophen \\ MIGAL-Scientific Research Institute, \\ POB 831 Kiryat Shmone 11016 Israel.
}

\begin{abstract}
A brief historical (1956-2014) review of the Lake Victoria ecological development is presented. The Lake Victoria ecosystem structure was thoroughly modified after the invasion of the predator fish Lates niloticus (Nile perch). The relative capacity and functional activity of the food-web compartments was quantitative and qualitative altered. The trophic status of Lake Victoria ecosystem was shifted toward eutrophication: phytoplankton species composition and densities were modified, fish assemblages were converted from about $\mathbf{4 0 0}$ Haplochromine species diversity to large body predator, Nile perch dominance. Consequently, the fishery was changed accompanied by Socio-Economic consequences. The thermal structure trait shifted towards enhancement of anoxia and Hypolimnetic volume extension.
\end{abstract}

\section{INTRODUCTION}

Lake Victoria is the second-largest lake (excl. Caspian Sea) in the world by surface area and $7^{\text {th }}$ by Volume: Maximum Length-337 km and Maximum Breadth-250 km. The lake is located at an altitude of 1134 MASL and a latitude between $0^{\circ} 20^{\prime} \mathrm{N}-3^{\circ} 0^{\prime} \mathrm{S}$ and $31^{\circ} 39^{\prime} \mathrm{W}-34^{\circ} 53^{\prime} \mathrm{E}$. Lake Victoria is a source of livelihood for over 35 million people in Kenya, Tanzania and Uganda (Figure 1). Limnological features of the lake are given in Table 1 (Newell 1960).

Table 1: Limnological Features of Lake Victoria.

\begin{tabular}{|c|c|}
\hline Basin Area & $239,000 \mathrm{~km}^{2}$ \\
\hline Lake Surface Area & $68,800 \mathrm{~km}^{2}$ \\
\hline Lake Volume & $2800 \mathrm{~km}^{3}$ \\
\hline Shoreline & $3440 \mathrm{~km}$ \\
\hline Shoreline Development Value (D)* & 3.7 \\
\hline Lake Volume(V)/Catchment Area(S) $\left(\mathrm{m}^{3} / \mathrm{m}^{2}\right)$ & 11.7 \\
\hline Maximum Depth & $83 \mathrm{~m}$ \\
\hline Mean Depth & $40 \mathrm{~m}$ \\
\hline \multicolumn{2}{|l|}{ Water Budget (Annual) } \\
\hline Total Inflow & $118 \mathrm{~km}^{3}$ \\
\hline Direct Rain & $100 \mathrm{~km}^{3}$ \\
\hline River Inflow & $18 \mathrm{~km}^{3}$ \\
\hline Total outflow & $118 \mathrm{~km}^{3}$ \\
\hline Evaporaton & $100 \mathrm{~km}^{3}$ \\
\hline River Outflow & $18 \mathrm{~km} 3$ \\
\hline Residence Time & 23.4 Years \\
\hline
\end{tabular}

${ }^{*} \mathrm{D}=$ The ratio of the length of the shoreline to the length of the circumference of a circle of an area is equal to that of the lake. The higher the number is, the more winding is the shoreline. $\mathrm{D}$ number for Lake Kinneret is 1.16 , and $\mathrm{V} / \mathrm{S}=1.5$. The strong impact of the drainage basin and the shoreline/lake water contact on nutrient inputs is therefore indicated. As of the late 1990`s, the annual fishery harvests within the Kenyan part of Lake Victoria was $70 \mathrm{Kg} / \mathrm{ha}$ due to about 
42,000 fishers and 10,500 boats (excluding Trawlers). The hydrological information in table 1 indicates the followings: Direct rain contributes $85 \%$ of total input, whilst the rest is by inflow rivers. Evaporation accounts for 85\% of the outputs. In early 1950's specimens of the piscivore (predator) fish, the Nile Perch (Lates niloticus Linnaeus, 1758) were removed from Lakes Albert and Turkana and stocked in Lake Victoria, accompanied by scientist concerns (Fryer 1960; Barel et al. 1985). Twenty years later, the Nile Perch comprised $>50 \%$ in catches. From the early 1980's years later this fish produced $>90 \%$ of landings. Before the Nile Perch invasion, the lake was densely populated by more than 400 endemic species of Haplochromine cichlids (Ochumba et al. 1992a; b). As a result of the Nile Perch piscivore feeding habits, the Haplochromid cichlids, as well as 6 introduced and 2 native species of Tilapia, were severely suppressed (Kaufman 1992). As a consequence, non-grazed algal biomass was accumulated, and progressive build-up of physico-chemical changes enhanced anoxia. Anoxic waters have been found at shallower depths and longer time due to an increase of oxygen demands for accumulated organic decomposition in the Hypolimnion. Landings composition also changed significantly. Haplochromid cichlids declined, and the portion of the exotic, Nile Perch, and the native Nile Tilapia (Oreochromis niloticus, Linnaeus 1758) and Silver Cyprinid (Rastrineobola argentea, Pellgrin, 1904) were significantly enhanced. Nevertheless, overfishing also took place (Ochumba et al. 1992a; Ojwang et al. 2014; Akiyama et al. 1997; Asila and Ogari 1987). Moreover, Lake Victoria Ecosystem has undergone successive changes within the drainage basin such as industrialization, agricultural development, dam constructions, deforestation and soil erosion. The combined external (urban, industrial, dust deposition, soil erosion, deforestation, agricultural fertilizers) and internal pollution processes resulted by the Nile Perch invasion enhanced deterioration of water quality. Presently, the Lake Victoria ecosystem clearly exhibits symptoms of Eutrophication (Ochumba et al. 1994a,b; Gophen et al. 1995).

\section{Fishery}

\section{ECOSYSTEM STRUCTURE MODIFICATIONS}

The dramatic changes resulted by the introduction of Nile Perch (1954) and the massive species extinction of Haplochromines include many aspects of limnological features especially fishery harvest composition (Table 2). 
Table 2: Fishery in the Kenyan part of Lake Victoria during 1968-1989. The percentage (\%) of major landing components (Nile Perch, Haplochromines, Tilapias, Rastrineobola argentea) are given and the annual total (tons $\mathrm{X10}^{3} / \mathrm{y}$ ) landings are given.

\begin{tabular}{|c|c|c|c|c|c|}
\hline $\begin{array}{c}\text { Total } \\
\text { (tonsX10 }\end{array}$ & Tilapias(\%) & $\begin{array}{c}\text { Rastrineobola } \\
\text { argentea (\%) }\end{array}$ & $\begin{array}{c}\text { Haplochro- } \\
\text { mines(\%) }\end{array}$ & $\begin{array}{c}\text { Lates } \\
\text { Niloticus(\%) }\end{array}$ & Year \\
\hline 16 & 15 & 5 & 23 & $<1$ & 1968 \\
\hline 17 & 27 & 3 & 37 & $<1$ & 1969 \\
\hline 16 & 28 & 3 & 33 & $<1$ & 1970 \\
\hline 15 & 21 & 5 & 32 & $<1$ & 1971 \\
\hline 16 & 15 & 8 & 29 & $<1$ & 1972 \\
\hline 17 & 10 & 11 & 33 & $<1$ & 1973 \\
\hline 17 & 6 & 22 & 35 & $<1$ & 1974 \\
\hline 17 & 4 & 27 & 28 & $<1$ & 1975 \\
\hline 19 & 5 & 30 & 34 & $<1$ & 1976 \\
\hline 19 & 7 & 35 & 32 & 1 & 1977 \\
\hline 24 & 11 & 37 & 28 & 5 & 1978 \\
\hline 31 & 9 & 31 & 22 & 14 & 1979 \\
\hline 27 & 19 & 35 & 14 & 16 & 1980 \\
\hline 46 & 10 & 20 & 2 & 60 & 1981 \\
\hline 61 & 7 & 17 & 4 & 54 & 1982 \\
\hline 77 & 6 & 21 & 1 & 68 & 1983 \\
\hline 72 & 10 & 27 & 0 & 58 & 1984 \\
\hline 90 & 11 & 29 & 0 & 57 & 1985 \\
\hline 103 & 3 & 31 & 1 & 64 & 1986 \\
\hline 113 & 3 & 25 & $<1$ & 69 & 1987 \\
\hline 125 & 2 & 37 & $<1$ & 59 & 1988 \\
\hline 135 & 2 & 39 & 2 & 54 & 1989 \\
\hline
\end{tabular}

Results in Table 2 indicate the following changes of landing composition during 1968-1989 in the Kenyan region of Lake Victoria: Significant increase of Rastrineobola $\left(r^{2}=0.693\right)$, Nile Perch $\left(r^{2}=0.538\right)$, and the total $\left(r^{2}=0.767\right)$ whilst landing of Haplochromines and Tilapias declined significantly: $\mathrm{r}^{2}=0.538$ and 0.524 , respectively. The outcome of those modifications ascribed ecosystem perturbation. Such an abrupt destruction of natural Haplochromine diversity has never before been documented. The Haplochromine community in Lake Victoria comprises of approximately 400 species encompassing remarkable wide trophic spectrum. This wide spectral diversity resulted in a young $\left(14 \times 10^{3} \mathrm{BP}\right.$ when the lake was completely dried up) isolated ecosystem part of the Nile system. The Haplochromine community diversified into more than $50 \%$ plankton-detritus consumers of which $55 \%$ were detritivores and $27 \%$ zooplanktivores. Since its introduction in 1954 until 1980, the Nile Perch population has abruptly expanded and the Haplochromine population decline was accompanied. Several consequences followed. Fish consumption of phytoplankton and detritus reduced. The zooplanktivore Rastrineobola argentea population was enhanced and zooplankton was suppressed. The density of the prawn Caridina nilotica was enhanced, mostly in deep waters. The fishery and fish industry were modified from the balanced pressure on the small size Haplochromines, for local consumption to Trawling and Hook-Bait fishery of large body Nile Perch mostly for export and partly for local consumption. The limnological alteration that accompanied the Nile Perch expansion forwarded Eutrophication by increasing Hypolimnetic anoxia and shorter period of extensive vertical mixing; an increase of phytoplanktonic primary production with composition shift from Diatoms to Cyanophytes dominance. Moreover, the impact of anthropogenic activity in the drainage basin of deforestation, urbanization and industrialization enhanced inputs of Nitrogen and Phosphorus into the lake together with the decline of available Silica. Conclusively, eutrophication trait was enhanced both as top-down and bottom-up Eco-forces. Those Limnological alterations are probably sub-optimal conditions 
for Haplochromine fishes. Major ecosystem modification in Lake Victoria after the 1960's induced by the Nile Perch invasion and environmental pollution led to the elimination of the native fish species of Haplochromines and Tilapias and prominent increase of the exotic Nile Perch and the pelagic small size native Rastrineobola. As a consequence the food-web structure was prominently modified.

\section{Phytoplankton and Zooplankton}

\section{ECOLOGICAL CHANGES}

Phytoplankton in Large lakes of the "Warm Belt" (Serruya and Pollingher 1983) is characterized by dominance of Chlorophyta and Cyanophyta and rarely by Diatoms. During the late 1990's, the Cyanophyta and Diatoms in Lake Victoria represented high diversity and densities but those of Chlorophytes were low. The densities of three other algal groups, Dynphyta, Cryptophyta and Euglenophyta, were low during the late 1990's. It has to be considered that in 1986 a heavy bloom of Microcystis was documented in Lake Victoria (Ochumba and Kibara 1989). Talling documented dominance of Diatoms and studies carried out 30 years later indicated the dominance of Cyanophyta. Phytoplankton research in Lake Victoria started in 1898 when expeditions were carried out to collect net hauling samples; therefore, information until the 1960's is limited to algal taxonomy. Talling $(1965 ; 1966)$ was the first who studied long-term cycle of community composition, quantitative abundance, population dynamics and vertical distribution and later, Kenyan and other scientists continued (Akiyama et al. 1977; Ochumba and Kibara 1989; Melack 1979). The Zooplankton of Lake Victoria was studied by Rzoska and others (Rzoska 1956,1978; Mavuti and Litterick 1991). The phytoplankton assemblages as indicated during the late 1990's are characterized by high densities of Coccoids accompanied by small filaments of Cyanophytes (Lyngbia). Diatoms were presented by Nitzchia and Melosira (Aulacoisera) and the Chlorophytes by Chlorococcales and Desmids. Dinophytes and Cryptophytes were rarely observed. The densities of zooplankton were mostly low and their body size small. The most abundant group was Cyclopoid Copepods. Unpredicted results of feeding experiments confirmed that most of the organisms that were removed from the water by the fish were free-swimming small body zooplankters and gut content composition comprised of specimens collected in the lake indicated them as inhabitants of deep and bottom-layer organisms. It is, therefore, suggested that as a result of the Nile Perch invasion Tilapias were pushed by the Perch downward to find a refuge space where they can be better protected. The bottom habitat was utilized by Tilapias as a refuge and, therefore, bottom organisms were preyed and observed in the Tilapias' gut contents. A schematic chart of the Lake Victoria trophic structure before and after 1980 is presented in Figure 2.

Ecosystem Structure Before 1980 (Figure 2 right panel): Optimally balanced food-web, sufficient grazing pressure by planktivorous Haplochromines (Greenwood 1981), low level of algal biomass and consequently Primary Production. No surplus of organic matter, low sedimentation and low level of anoxia. Nevertheless, an increase in the input of pollutants was indicated: N-after 1920 and P-after 1950. Low annual fish catches mostly comprised of small size Haplochromines and avoidance of overfishing.

Ecosystem Structure After 1980 (Figure 2 left panel): Food web structure exhibits disequilibrium. Grazing level declines due to elimination of grazer Haplochromines and dominance of the predator Nile Perch. Therefore, increase of non-grazed algal biomass (chlorophyll elevation) followed by higher Primary Production accompanied by accumulation of surplus organic matter and sedimentation resulted in enhanced anoxia. Secchi depth and the thickness of the euphotic zone became shallower as a result of higher densities of suspended matter and decline of light penetration (Silsbe et al. 2006; Kling et al. 2001; Hecky et al. 2010). 
Decline of available Silica and SRP (Soluble Reactive Phosphorus) and the decline of TN/TP mass ratio were probably the reason for the replacement of Diatom before 1980 to Cyanobacteria dominance after 1980 (Table4). Another outcome of those changes was the proliferation of the detritivorous Atyid-Decapod Caridina nilotica. The total annual fishery harvest was significantly enhanced as a result of the optimal conditions for the reproduction and growth of the Nile Perch. Comparative data of several parameters (ranges: Max.-Min) of Limnological features documented in Lake Victoria (1960-1990) are given in Table 3.

Table 3: Comparative ranges of limnological features documented in Lake Victoria during 1966-1994 by: Talling (1966), Akiyama et al. (1977), Ochumba and Kibaara (1989), Hecky and Mungoma (1994), and Gophen et al. (1994).

\begin{tabular}{|l|c|c|c|c|}
\hline Lake Zone & $\begin{array}{c}\text { Depth(m): } \\
\text { Average(SD) }\end{array}$ & $\begin{array}{c}\text { Depth (m): } \\
\text { Range }\end{array}$ & $\begin{array}{c}\text { Secchi depth } \\
\text { (m) (SD) }\end{array}$ & $\begin{array}{c}\text { Upper Anoxic } \\
\text { Layer (m) (SD) }\end{array}$ \\
\hline $\begin{array}{l}\text { Rusinga } \\
\text { Channel - Deep }\end{array}$ & $47(5)$ & $30-56$ & $2.0(0.3)$ & $22(15)$ \\
\hline $\begin{array}{l}\text { Rusinga } \\
\text { Channel - } \\
\text { Shallow }\end{array}$ & $8(2)$ & $4-11$ & $1.5(0.2)$ & NO \\
\hline Wynam Gulf & $8(4)$ & $3-15$ & $1.4(0.3)$ & NO \\
\hline Offshore & $40(8)$ & $28-66$ & $2.1(0.3)$ & $23(7)$ \\
\hline
\end{tabular}

Recent documentation of limnologicalproperties in the Uganda and Kenya regions of Lake Victoriaare summarized in Table 4.

Table 4: Comparative data from Lake Victoria: 1960-Uganda-Talling (1965; 1966); Uganda1990; Kling et al. 2001; Hecky et al. 2010; Silsbe et al. 2006); Kenya 1990-Gophen (2015a,b,)

\begin{tabular}{|c|c|c|c|c|c|c|}
\hline 1990 & 1989 & 1984 & 1979 & 1977 & 1966 & Parameter \\
\hline $0.1-19$ & $4.0-37.0$ & $0.2-75$ & & $0.1-122$ & $7.0-120$ & P-PO4( $\mu \mathrm{g} / \mathrm{l})$ \\
\hline \multirow{2}{*}{$1.0-30$} & $0.1-513$ & 2.1-237 & $0.16-0.18$ & $0.5-122$ & $10.0-112$ & $\mathrm{~N}-\mathrm{NO} 3(\mu \mathrm{g} / \mathrm{l})$ \\
\hline & & $0.1-5.0$ & & & $0.4-4.0$ & $\mathrm{~S}-\mathrm{SO} 4(\mathrm{mg} / \mathrm{l})$ \\
\hline \multirow[t]{2}{*}{$\begin{array}{c}0.06- \\
0.72 \\
\end{array}$} & & $0.1-7.6$ & $2.0-7.9$ & $0.2-3.0$ & $4.0-8.0$ & $\begin{array}{l}\mathrm{Si}- \\
\mathrm{SiO} 2(\mathrm{mg} / \mathrm{L})\end{array}$ \\
\hline & $0.2-2.1$ & $0.35-2.4$ & & $1.2-2.0$ & $1.0-3.9$ & $\begin{array}{l}\text { Secchi } \\
\operatorname{Depth}(\mathrm{m})\end{array}$ \\
\hline $\begin{array}{l}100- \\
1400\end{array}$ & $180-600$ & & $400-600$ & & $100-130$ & $\begin{array}{l}\mathrm{PP} \\
(\mathrm{mgO} 2 / \mathrm{m} 3)\end{array}$ \\
\hline \multirow[t]{3}{*}{$\begin{array}{l}35.8- \\
115.2 \\
\end{array}$} & $8.0-120$ & $1.8-23.5$ & & $2.1-8.5$ & $0.5-22.3$ & $\begin{array}{l}\text { Chlorophyll } \\
\text { (mg/l) }\end{array}$ \\
\hline & Cyanophytes & Cyanophytes & Diatoms & Diatoms & Diatoms & $\begin{array}{l}\text { Algal } \\
\text { dominance }\end{array}$ \\
\hline & & Thermocyclops & & Copepods & & $\begin{array}{l}\text { Zooplankton } \\
\text { Dominance }\end{array}$ \\
\hline
\end{tabular}

Data in tables 3 and 4 indicates that Cyanobacteria replaced Diatoms, Secchi Depth became shallower, i.e. turbidity enhancement, the euphotic zone became thinner due to increase of turbidity and decline of light penetration, increase of algal density accompanied by elevation of primary production and organic matter content which caused an increase of anoxia. Moreover, total lake primary production as computed for the entire lake (tons Carbon assimilated annually) indicated an increase from $1.7 \times 10^{7} \mathrm{t}$ during the 1960 's to $10.5 \mathrm{X} 10^{7} \mathrm{t}$ during the 1990's (Silsbe et al. 2006; Kling et al. 2001; Hecky et al. 2010). Annual Fish landing increased from 25,000 tons to 500,000 tons between the 1960's and 1990's. Consequently percentage of fish catch relative to Primary Production was increased from $0.01 \%$ to $0.05 \%$ and the depth of the Thermocline became shallower by 30 meters (from 60 to $30 \mathrm{~m}$ ) (Silsbe et al. 2006; Kling et 
al. 2001; Hecky et al. 2010). The food Web pattern of energy flow was prominently modified and Lake Victoria before the 1980's is different from that established after the 1980's (Figure 2). Figures 3-5 represent the changes of thermal structure trait resulted by those modifications of the food web structure. The fish faunal composition was modified from the dominant native Haplochromines which were replaced by the exotic Nile Perch and native Rastrineobobla (Kaufrman 1992). Landing data for the period of 1968-1992 indicates a prominent temporal change of annual harvests Vs years started in 1980: Lates Niloticus $\left(r^{2}=0.805 ; p=0.0001\right)$, Rastrineobola $\left(r^{2}=0.693 ; p=0.0001\right)$ and consequently the total $\left(r^{2}=\right.$ 0.767; $p=0.0001)$ were sharply increased whilst that of Haplochromins $\left(r^{2}=0.538 ; p=0.0001\right)$ declined. Nile Perch and Rastrineobola comprised a significant part of the total catch and the impact of Tilapias was insignificantly slight elevation and that of Haplochromine significantly reduced. Lake Victoria is presently exhibiting traditional symptoms of eutrophication: the decline of water transparency, Cyanobacteria dominance, elevation of $\mathrm{P}$ and decline of $\mathrm{N}$ levels, an increase of algal biomass (chlorophyll concentration), shallower Secchi depth, thinner euphotic zone and anoxia enhancement. Future management design of fishery in Lake Victoria must, therefore, be done very carefully. Distinct objectives are proposed: 1) reduction of pollutant inputs caused by anthropogenic activity; 2) increased level of phytoplankton grazing. The second target is difficult due to the intensive predation pressure produced by the Nile Perch. Relevant fish species might be planktivorous large body (probably not preyed by Nile Perch)Tilapias. The small body size Haplochromine fishes are vulnerable for predation and, therefore, not suitable for management if aimed at enhancement of planktivory. Whilst the large body size of the planktivorous Tilapias are less vulnerable to Nile Perch predation and therefore optimal for management of planktivory enhancement.

\section{THERMAL STRUCTURE}

\section{Changes:}

The impact of the Nile Perch invasion also affected indirectly the thermal structure and physico-chemical $(\mathrm{pH})$ alterations (Table 5):

Table 5: Total average (SD) of Maxima, Minima and range of $\mathrm{pH}$ and Temperature measured in all stations and dates during 1990-1992 $(\mathrm{n}=246)$.

\begin{tabular}{|l|c|}
\hline Maximum pH & $8.50(0.87)$ \\
\hline Maximum Temperature & $26.2(2.8)$ \\
\hline Minimum pH & $7.35(0.71)$ \\
\hline Minimum Temperature & $25.2(2.8)$ \\
\hline pH Rang & $1.16(0.78)$ \\
Temperature Range & $2.9(2.7)$ \\
\hline
\end{tabular}

Total $(n=155)$ average of Secchi depths measurements: $1.8 \mathrm{~m}$ (SD 0.4m) with Min.-Max. range of 0.8-2.8 m. Figure 3 represents daily changes of stratification. The daily thermal dynamics represent a normal pattern which is typical to deep lakes although the amplitude of the regime extremes is low as documented in the tropics. A clear formation of the thermo-oxycline and a minor difference between Hypolimnion and Epilimnion were indicated. Consequently, the stabilization level of the thermal structure is probably low and potential for mixing is high. Moreover, the significant relationship between temperature and $\mathrm{pH}$ gradients that was also documented probably reflect the typical correlation between daily increase of temperature, and light intensity which accompany enhancement of photosynthetic activity resulting $\mathrm{pH}$ increase (Figure 4). A slight increase of the monthly means of the oxycline (<4.0 ppm DO) during relatively short period (1990-1991: 14 months) (Figure 5) exemplify the potential long term impact of thermal changes following eutrophication trend. The documented values of $\mathrm{pH}$ and temperature represent a low level of fluctuated amplitude. Previous documented data has 
indicated that Secchi Depths in Lake Victoria became shallower by 2-3 m from the mid-1960's to early 1990's. Talling (1966) documented, during the 1950's-1960's, Secchi depths between1.0 and 3.9 whilst our research revealed indicated shallower values of 0.8$2.8 \mathrm{~m}$. Documentation about anoxic water $(<4.0 \mathrm{ppm}$ DO $)$ in the Kenyan part of Lake Victoria was reported 26 times during 1985-1987 in March, May and August by several authors. These anoxic waters were recorded at station depths which varied between 5 and $30 \mathrm{~m}$ whilst the upper boundary of the anoxia was at 4.5-25 m. Very low concentrations of DO $(<4.0 \mathrm{ppm})$ recorded in bottom waters at offshore Stations (30-60 m) were also documented by several authors during 1957-1989 (Fish 1957). It is suggested that the disappearance of anoxia from the deeper $(>30 \mathrm{~m})$ part of Rusinga Channel that we measured during 08:00-09:00 am in 24.8.1990 (Fig.3) was driven by internal Seiche movement which injected the anoxic waters into the shallows $(<10 \mathrm{~m})$ as we measured in two other profiles (not shown here). Lake Victoria has undergone modifications initiated by both the invasion of the exotic Nile Perch (Gophen et al. 1993) and the anthropogenic activity in the catchment (Reynolds and Grebovall 1988). The Nile Perch invasion into Lake Victoria was accompanied by anthropogenic activities and the development of pollution created the deleterious changes in the entire ecosystem and resulted in the physico-chemical conditions. During 7 months (II-IV, VII-IX, and XI) in 1990-1991 no anoxic conditions were recorded in the Rusinga Channel as well as in two stations in the offshore waters during two months (II-III) (Table 6, 7). Prior to the Nile Perch invasion, the upper depths of anoxic waters were measured between 45 and 75 m (Newell 1960; Kaufman 1992; Akiyama et al. 1977; Talling 1957; Kitaka 1971), whereas we (1990-1991) found it at an average depth of 22-23m. Hourly monitoring in station 34, which is located on the marginal zone of the hypolimnetic water mass, confirmed Seiche movements and the existence of anoxia during August-October in the water layer below $23 \mathrm{~m}$ of the Rusinga Channel. It is, therefore, suggested that a significant area of the deeper part of the lake $(>23 \mathrm{~m})$ is consistently anoxic during a long period. 
Table 6: Surface water and upper layer of anoxic water temperatures, bottom and anoxic water depth, measured in deep stations (see map) during 1990-1991 by HYDROLAB System.

\begin{tabular}{|c|c|c|c|c|c|}
\hline Station & Month & $\begin{array}{c}\text { Bottom } \\
\text { Depth }\end{array}$ & Day Time & $\begin{array}{c}\text { Upper Anoxic } \\
\text { Depth }\end{array}$ & $\begin{array}{c}\text { Surface Temp./Anoxic } \\
\text { Temp. }\end{array}$ \\
\hline $\begin{array}{c}\text { Kisumu } \\
\text { Bay }\end{array}$ & $\mathbf{3}$ & $\mathbf{7}$ & $\mathbf{1 5 : 3 0}$ & $\mathbf{1 0}$ & $\mathbf{2 7 . 5 0 / 2 5}$ \\
\hline 100 & 3 & 33 & $12: 10$ & 21 & $26.58 / 24$ \\
\hline 33 & 3 & 37 & $13: 40$ & 19 & $26.95 / 25$ \\
\hline 55 & 3 & 34 & $10: 25$ & 26 & $25.74 / 24$ \\
\hline 33 & 3 & 38 & $15: 05$ & 18 & $26.87 / 25$ \\
\hline 103 & 3 & 63 & $10: 45$ & 19 & $27.41 / 24$ \\
\hline 99 & 3 & 46 & $13: 20$ & 26 & $26.71 / 24$ \\
\hline 32 & 3 & 49 & $16: 00$ & 22 & $26.08 / 25$ \\
\hline 99 & 2 & 30 & & 29 & $25.83 / 25$ \\
\hline 100 & 2 & 39 & $10: 00$ & 31 & $26.20 / 25$ \\
\hline 32 & 2 & 40 & $12: 50$ & 37 & $26.85 / 25$ \\
\hline 33 & 2 & 37 & $13: 10$ & 32 & $26.09 / 26$ \\
\hline 33 & 2 & 35 & $14: 15$ & 33 & $26.02 / 25$ \\
\hline 34 & 2 & 45 & $09: 25$ & 40 & $27.06 / 24$ \\
\hline $34 \mathrm{~B}$ & 2 & 52 & $11: 35$ & 45 & $26.64 / 25$ \\
\hline 6 & 2 & 47 & $13: 40$ & 22 & $26.48 / 25$ \\
\hline 3 & 5 & 4 & $14: 00$ & 3.5 & $25.81 / 25$ \\
\hline 5 & 5 & 6.5 & $08: 15$ & 5.5 & $27.27 / 25$ \\
\hline 33 & 5 & 37 & $12: 30$ & 30 & $26.15 / 25$ \\
\hline 32 & 5 & 43.5 & $10: 20$ & 25 & \\
\hline 55 & 5 & 40 & $12: 00$ & & \\
\hline 100 & 5 & 34 & $13: 15$ & & \\
\hline 103 & 5 & 59 & $10: 25$ & & \\
\hline
\end{tabular}

\section{STRATIFICATION STABILITY}

Enhancement of external pollutant inputs together with the Nile Perch invasion are the major reasons for the deterioration of water quality and the devastation of the fishery and natural biodiversity of Hapolochromid fish assemblages in Lake Victoria. Independently, the thermal structure of Lake Victoria is very sensitive, which by itself is a potential support for pollution processes (Hecky et al. 1994) Lake Victoria is located in the tropical zone where the amplitude of temperature differences between day and night and seasonally are low. Moreover, the lake is not deep enough to form Meromixis structure of stable long tem stagnation of stable stratification as in other deep lakes in East Africa. Lake Victoria is not deep enough to form permanent non-mixed layers (Meromictic), and thermal changes are not high enough to create stable stratification. Nevertheless, daily changes of temperature accompanied by the pollution impact, Nile Perch invasion and a thorough modification of the food-web structure formed deleterious effects of water quality. The data presented in Table 5 indicates the instability of thermal stratification. Stability of stratification and water column mixing effect rely on thermal and consequently on density (weight/volume) differences between upper and lower layers. If thermal water differences and consequently densities are close, the potential for mixing is high. These criteria were formulated as Relative Thermal Resistance (R.T.R.). The RTR values are calculated for adjacent layers (could be half a meter and/or several meters thickness) accounted for their temperatures and consequent densities. In this paper the Epilimnetic water density is the conversion of Surface Temperature (S) to density. The Hypolimnetic water density is the conversion of the temperature of the upper layer of Anoxia (A). One unit of RTR is $8 \times 10^{-6}$. That is the difference between water density at $5^{\circ} \mathrm{C}(0.999992)$ and $4^{\circ} \mathrm{C}$, the highest water density $(1.000000)$. The higher the water temperature is, the lower 
is their density. The actual RTR value of the Lake Victoria water column is expressed as the Ratio between the density of "A" minus the density of "S" in relation to the density difference of $4^{\circ} \mathrm{C}$ and $5^{\circ} \mathrm{C}$. The higher the result is, the higher is the stratification stability, i.e. more energy is required for mixing. A significant indicator of the strong mixing activity within the water column of the offshore zone of Lake Victoria is also presented by the $\mathrm{pH}$ values' uniformity, ranged between 6.91 and 7.55 (one exception of 8.02). The significant relations as presented by linear regressions between the minimum temperatures and $\mathrm{pH}$ values as well as between the thermal ranges and $\mathrm{pH}$ values indicate the followings: There are two independent processes: 1) Photosynthesis resulting in DO production and $\mathrm{pH}$ increase, and 2) Thermal changes. Solar radiation is the only heat source (air temperature) and its distribution downwards is dependent upon water heat conductivity. The DO production and $\mathrm{pH}$ increase are primarily induced by phytoplanktonic photosynthesis, which are affected by daily elevation of light intensity and temperature. Data given in Table 7 emphasis the outcome of the long term processes previously discussed. The DO concentration as an indication of photosynthetic activity was higher in upper (0-20m) during 1990 as a result of higher algal biomass causing reduction of light penetration downwards (shading effect) resulted lower Do concentration during 1990 in deep waters (40-60m). Mixing Potential (RTR) RTR values for Lake Victoria was calculated for actual maximal and minimal S

(surface) and A (Anoxic) temperatures:

\section{Minima:}

$\mathrm{S}=25.74^{\circ} \mathrm{C}$; Density $(\mathrm{g} / \mathrm{ml})=0.996856$;

$\mathrm{A}=24.78^{\circ} \mathrm{C}$; Density $(\mathrm{g} / \mathrm{ml})=0.997104$;

Difference $=248 \times 10^{-6}$;

\section{Maxima}

$\mathrm{S}=27.41^{\circ} \mathrm{C}$;

Density

$(\mathrm{g} / \mathrm{ml})=0.996403$;

$\mathrm{A}=26.04 ;{ }^{\circ} \mathrm{C}$; Density $(\mathrm{g} / \mathrm{ml})=0.99776$;

Difference $=373 \times 10^{-6}$;

\section{RTR value:}

Minimal:248 X $10^{6} / 8 \times 10^{6}=\underline{31}$;

Maximal:373 X $10^{6} / 8 \times 10^{6}=\underline{46}$;

The RTR value for Lake Kinneret (Israel) where mean Epilimnetic and Hypolimnetic Temperatures are $26^{\circ} \mathrm{C}$ and $15^{\circ} \mathrm{C}$, respectively, converted to density units, is 290 . Consequently, stratification stability in Lake Kinneret is much higher than in Lake Victoria (Hecky et al. 2010).

The low stability of stratification in Lake Victoria is, therefore, a significant factor of nutrient input through an effective upwelling and mixing (Silsbe et al. 2006; Hecky et al. 2010) It is an efficient bottom-up eco-force contributing nutrients for phytoplankton growth. Monthly averages of DO concentration (ppm) and percentage saturation in two layers (0-20 m; 40-60 $\mathrm{m}$ ) in the Kenyan waters of Lake Victoria during the 1960's (Talling 1957; Hecky et al. 1994) and 1990's are given in Table 7. 
Table 7: Monthly Averages of DO concentration (ppm) and percentage saturation in the Kenyan waters of Lake Victoria during the 1960's and 1990's (Talling 1957; Hecky et al. 1994):

\begin{tabular}{|c|c|c|c|c|c|c|}
\hline Month & $\begin{array}{c}\text { ppm DO } \\
\mathbf{0 - 2 0 m} \\
\mathbf{1 9 6 0}\end{array}$ & $\begin{array}{c}\text { ppm DO } \\
\mathbf{0 - 2 0 m} \\
\mathbf{1 9 9 0}\end{array}$ & $\begin{array}{c}\text { ppm DO } \\
\mathbf{4 0 - 6 0 m} \\
\mathbf{1 9 6 0}\end{array}$ & $\begin{array}{c}\text { ppm DO } \\
\mathbf{4 0 - 6 0 m} \\
\mathbf{1 9 9 0}\end{array}$ & $\begin{array}{c}\mathbf{\%} \text { Saturation } \\
\mathbf{( 0 - 2 0} \mathbf{~ m}) \\
\mathbf{1 9 6 0}\end{array}$ & $\begin{array}{c}\text { \% Saturation } \\
\mathbf{( 0 - 2 0} \mathbf{~ m}) \\
\mathbf{1 9 9 0}\end{array}$ \\
\hline 9 & 7.1 & 8.9 & 3.48 & 3.25 & 96 & 138 \\
\hline 10 & 7.08 & 9.52 & 3.99 & 1.46 & 98 & 146 \\
\hline 11 & 6.94 & 6.17 & 3.48 & 0.52 & 97 & 109 \\
\hline 12 & 6.73 & 7.57 & 2.91 & 0.87 & 96 & 110 \\
\hline 1 & 6.71 & 7.6 & 4.34 & 2.20 & 91 & 112 \\
\hline 3 & 6.81 & 7.46 & 6.29 & 2.21 & 94 & 110 \\
\hline 4 & 5.15 & 6.15 & 1.79 & 3.76 & 94 & 122 \\
\hline 5 & 6.64 & 9.63 & 2.75 & 6.74 & 91 & 143 \\
\hline 7 & 6.59 & 8.43 & 6.34 & 7.72 & 90 & 115 \\
\hline 8 & 7.23 & 7.72 & 5.66 & 4.16 & 97 & 107 \\
\hline
\end{tabular}

Results in Table 7 show the following: Averaged DO concentration in shallow layer was 7.9 ppm and 6.7 ppm in 1990 and 1960 respectively, whilst in deep layer in 1960 and 1990 the concentration was 4.1 and 3.3 ppm respectively.

1) Higher D0 concentration in upper layer during the 1990's due to increase of phytoplankton biomass; 2) Lower DO concentration i.e. symptom of anoxia, in deep layer during the 1990's. The increase of photosynthetic activity in the upper layer during the 1990's is also expressed by the higher percentage of saturation. A verification of the anoxic enhancement and the close relation between DO and $\mathrm{pH}$ in Lake Victoria are presented in Table 6 and in Figures 3-5. The formation of a Thermocline at $5 \mathrm{~m}$ depth during 10:00 am and its decline to $10 \mathrm{~m}$ as expressed by Temperature, $\mathrm{DO}$ and $\mathrm{pH}$ at 15:00 pm. In the late afternoon (17:00-18:00), Thermocline decline to 20 meters was indicated together with anoxia ( $<4.0 \mathrm{ppm} \mathrm{D0}$ ) below $20 \mathrm{~m}$ (Figure 3). The four profiles measured at station 34 (Figure 3) during 08:55-15:15, indicates a formation of a Thermocline at $5 \mathrm{~m}$ and anoxia $(<4.0 \mathrm{ppm})$ accompanied by low $\mathrm{pH}(<7.0)$ below 20 meters during the daytime. The four profiles given in Figure 3 represent thermal changes during morning time in station 34. Thermocline formation at $10 \mathrm{~m}$ during 03:00 followed by a decline to $15 \mathrm{~m} 9 \mathrm{~m}$ one hour later and almost a complete destruction of stratification later at 05:00. During the late morning, a mass of oxidized waters penetrated below $40 \mathrm{~m}$ during 08:00 and one hour later it was detected at $30 \mathrm{~m}$ depth. Monthly averages (1990-1991) of the Thermocline depths are given in Figure 5. These data were statistically tested (linear and quadratic predictions) resulted in a decline of $8 \mathrm{~m}$ (from 27 to $19 \mathrm{~m}$ ) and $7 \mathrm{~m}$ (from 26 to 19 $\mathrm{m}$ ), during 1990 and 1991 respectively. When gradients (Max.-Min.) of Temperature and $\mathrm{pH}$ values (Figure 4) were tested by Linear regression $\left(\mathrm{r}^{2}, \mathrm{p}<0.01\right)$, the result has indicated a significant positive relationship. The formation of stratification and its abrupt destruction (Talling 1969), the quick and slight changes of water temperature, oxygen content and $\mathrm{pH}$, prominently presented (Figures 3-5) exhibit the low stability of the thermal structure.

\section{THE DRAINAGE BASIN}

The lake and the drainage Basin territories are shared between three countries: Kenya, Tanzania and Uganda. The ratio between Catchment area and lake Volume is $11.7 \mathrm{~m}^{3} / \mathrm{m}^{2}$.The significance of that value is that each $\mathrm{m}^{3}$ of the lake accepts nutrients from $11.7 \mathrm{~m}^{2}$ of the catchment, which is, for example, much higher than that of Lake Kinneret $\left(1.8 \mathrm{~m}^{3} / \mathrm{m}^{2}\right)$. Moreover, the consequence of the high D number for Lake Victoria (3.7) (1.16 for Kinneret) intensifies the contact between land and water fronts, which enhance nutrient fluxes from the catchment. The basin is covered by grassland, savanna, crops, urban centers and forested 
mountains (Burundi). Nevertheless, anthropogenic deforestation followed by soil erosion was intensively enhanced. Among the intensification of anthropogenic activities which enhanced pollutant contributions, the followings are prominent: production of domestic sewage (nutrients and pathogenics), Coffee processing, Textile industry, Soap factories, Oil Mills, Breweries, Dairy products, Paper production and Packing industries, Starch and Flour mills, Tannery, Pharmaceuticals, Sial, Beer and soft drinks production, Pesticides, Insecticides, Herbicides, and Molluscacides. Disease vectors (Bilharzia, Malaria) and grass overgrazing were enhanced.

\section{References}

Akiyama, T. Kajumulo, A.,A.,and Olsen S. 1977. Seasonal Variation of Plankton and physico-chemical condition in Mwanza Gulf, Lake Victoria. Bull. Freshwat. Fish. Res. Lab.27: 49-61.

Asila, A., and Ogari, J., 1987. Growth parameters and mortality rates of Nile Perch Lates niloticus estimated from length frequency data in the Nyanza Gulf (Kenya) Lake Victoria. FAO Fish. Rep. 389: 271-287.

Barel, C. D. N., Dorit, R., Greenwood, P. H., Fryer, G., Hughes, N., Jackson, P. B. N., Kawanabe, H., Lowe-McConell, R., H., 1985. Destruction of Fisheries in Africa`s lakes. Nature, 325: 19-20.1] Newell, B. S. 1960, Hydrology of Lake Victoria.Hydrobiologia, 15: 363-383.

Fish, G. R. 1957. A seiche movement and its effect on the hydrology of Lake Victoria. Col. Off. Fish. Publ. London 10: 1-60.

Fryer, G. 1960. Concerning the proposed introduction of Nile Perch into Lake Victoria. East. Afr. Agric. J. April 1960. 267-270.

Gophen, M., P. B. O. Ochumba, U. Pollingher and L. S. Kaufman. 1993. Nile Perch (Lates niloticus) invasion in Lake Victoria (East Africa). Verh. Internat. Verein. Limnol. 25:856-859.

Gophen, M., P. B. O. Ochumba, and L. S. Kaufman. 1995. Some aspects of perturbations in the structure and biodiversit of the Ecosystem of Lake Victoria. Aquatic Living Resources 8,(1):p. 27-41.

Gophen, M. 2015, a, Ecological devastation in Lake Victoria: Part A: Thermal Structure and Anoxia. Open Journal of Ecology,5, 287-298. http://dx.doi.org/10.4236/oje.2015.57023.

Gophen, M. 2015,b, Ecological devastation in Lake Victoria: Part B: Plankton and Fish Communities. Open Journal of Ecology,5,.315-325.

Greenwood, P. H. 1981. The Haplochromine fishes of East African lakes: Taxonomy, biology, and Evolution. Kraus InternationalPublications, Munich, 839 p.:6

Hecky, R. E., F. W. B. Bugenyi, P. B. O. Ochumba, J. F. Talling, R. Mugidae, M. Gophen, W. Robinson and L. S. Kaufman. 1994. Deoxygenation of the hypolimnion of Lake Victoria. Limnol. Oceanogr. 39(6):1476-1481.

Hecky, R. E., Mugidde, R., Ramlal, P. S., Talbot, M. R., and Kling, G. W. 2010, Multiple stressors cause rapid ecosystem change in Lake Victoria. Freshwat. Biol. 55: 19-42.

Kaufman, L., S., 1992. Catastrophic change in species-rich Freshwater Ecosystems: The lesson of Lake Victoria. BioScience (1992) 42 (11): 846-858.

Kitaka, G.E.B. 1971. An instance of cyclonic upwelling in the southern offshore waters of Lake Victoria. Afr. J. Trop. Hydrobiol.Fish. 1: 85-92.

Kling, H. J., Mugidde, R., Hecky R. E., 2001. Recent changes in the phytoplankton community of Lake Victoria in response to Eutrophication, ; in: Munawar, M., and Hecky, R. E., eds. The Great lakes of the world (GLOW), Food Web, Health and Integrity. Netherlands, Backhuys Pulishers, pp. 47-65.

Mavuti, K.M. and Litterick, A. M. 1991, Composition, Distribution and Ecological Role of Zooplankton Community in Lake Victoria, Kenya Waters; Verhandlungen des Internationalen Verein Limnologie, 24, 1117-1122.

Melack, J. M. 1979. Photosynthetic rates in four Tropical African Freshwatrs. Freshwat. Biol. 9: 555-571.

Newwell, B. S. 1960, Hydrology of Lake Victoria. Hydrobiologia, 15: 363-383.

Ochumba P. B. O. and D.I. Kibara 1989. Onbservation on blue-green akgal blooms in the open waters of Lake Victoria, Kenya. African Journal of Ecology, 27: 23-24. 
Ochumba, P. B. O., Gophen, M. and U. Pollingher. 1992a. Ecological changes in Lake Victoria after the invasion of Nile Perch (Lates niloticus): The catchment, water quality, and fishery management. Aquaculture and Schistosomiasis: proceedings of the network meeting, Manila, The Philipines. National Academy Press, Washington, DC 137-147.

Ochumba, P.O.B., M. Gophen and U. Pollingher. 1992b. Management of limnology and fisheries of Lake Victoria: General characteristics, sociogeographic and management of the fisheries. Hydraulic Enigneering in Mexico, Vol. VII, Nos 2/3/May-December, 1992. pp. 37-43.

Ochumba, P. B. O., M. Gophen and U. Pollingher. 1994a. Ecological changes in Lake Victoria after the introduction of Nile Perch (Lates niloticus): the catchment, water quality and fisheries management. In: Rehabilitation of Freshwater Fisheries (I. G. Cowx, ed.). Fishing News Books. Blackwell Scientific Publications Ltd. Chapter 31:pp. 338-347.

Ochumba, P.B.O., M. Gophen, and U. Pollingher. 1994b. Ecological Changes in Lake Victoria after the invasion by Nile perch (Lates niloticus). in: Recent Trends in Research on Lake Victoria Fisheries. Proceeding of the second EEC Regional Seminar on Recent Trends in Research on Lake Victoria Fisheries. Organized and hosted by Kenia Marine and Fisheries Research Institute (KMFRI). 25-27 September 1991, Kisumu, Kenia. (E.Okemwa, E.O. Wakwabi, and A. Getabu, eds.) ICIPE Science Press. pp.29-39.

Ojwang, W., O., J. E. Ojuok, C. Nyamweya, S. Agembe, M. Owili, E. Yongo, and E. O. Wakwabi. 2014. The intriguing dynamics of Rastrineobola argentea fishery in the Kenyan waters of Lake Victoria. Aquatic Ecosystem Health and Management 01/2014; 17 (1). DOI: 10.1080/14634988.2014.879036.

Reynolds, J. E. and Grebovall, D. F. 1988. Socio-Economic effects of thye evolution on Nile Perch Fisheries in Lake Victoria: A review: CIFA Tech. Rep. 17,148 p.

Rzoska, J. 1956. The Planktonic Crustacea of Lake Victoria. Proc. Linnean Soc. Lond. 168: 116-125.

Rzoska, J. (ed.) 1978. Zooplankton of the Nile System. in: The Nile. Biology of an Ancient River. pp. 333-343. Dr Junk Publishers, The Hgue.

Serruya, C. and U. Pollingher 1983, Lakes of the Warm Belt,. Cambridge: Cambrudge University Press, 569, p. Silsbe, G. M., Hecky R. E., Guildford. S. J., and Mugidde, R., 2006. Variability of Chlorophyll and Photosynthetic parametars, in a nutrient-saturated tropical great lake. Limnol. Oceanogr. (51), 6: 2052-2063.

Talling, J. F. 1957. Some Observations on the stratification of Lake Viktoria. Limnol. Oceanogr.3: 213-221

Talling, J. F., 1965. The Photosynthetic activity of Phytoplankton in East African Lakes. Int. Rvue. Ques. Hydrobiol. 50: $1-32$

Talling, J. F. 1966. The annual cycle of stratification and phytoplankton growth in Lake Victoria (East Africa). Int.Revue. Ques. Hydrobiol. 51: 545-621.

Talling, J. F. 1969. The incidence of vertical mixing and some biological and chemical consequences in tropical African lakes. Verh. Int. Ver. Limnol. 17: 998-1012. 


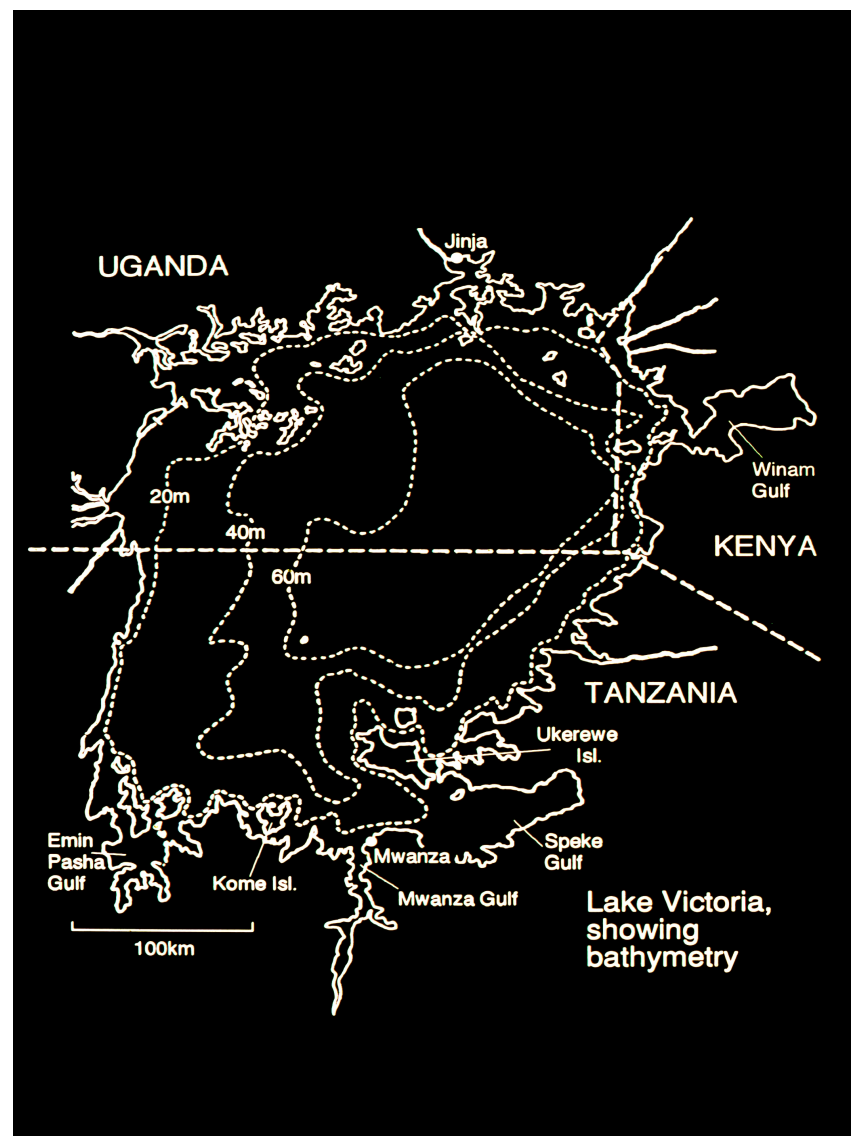

Figure 1:

Bathimetrical Map of Lake Victoria

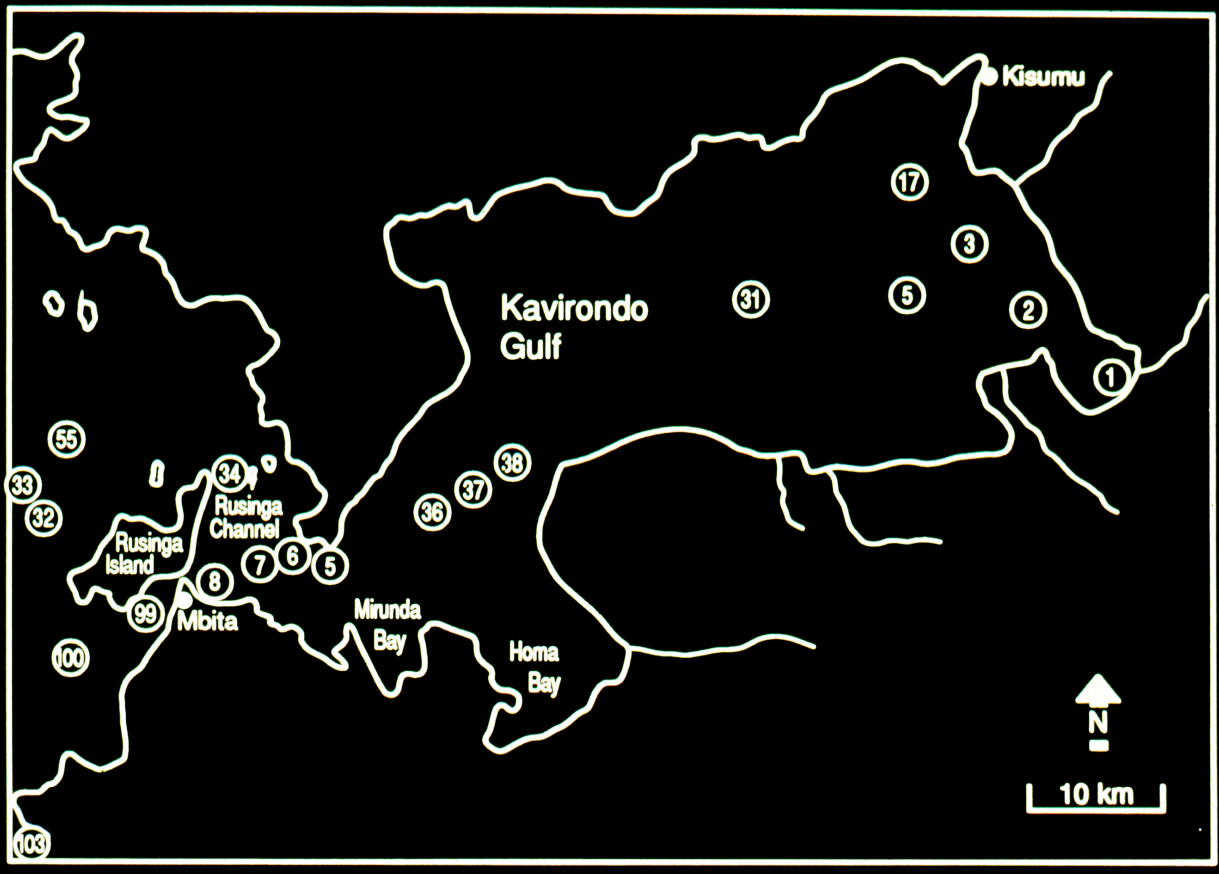

Figure 2: The Kenyan Part of Lake Victoria Kavirondo, (Wynam) Gulf

Sampling Stations are numbered 


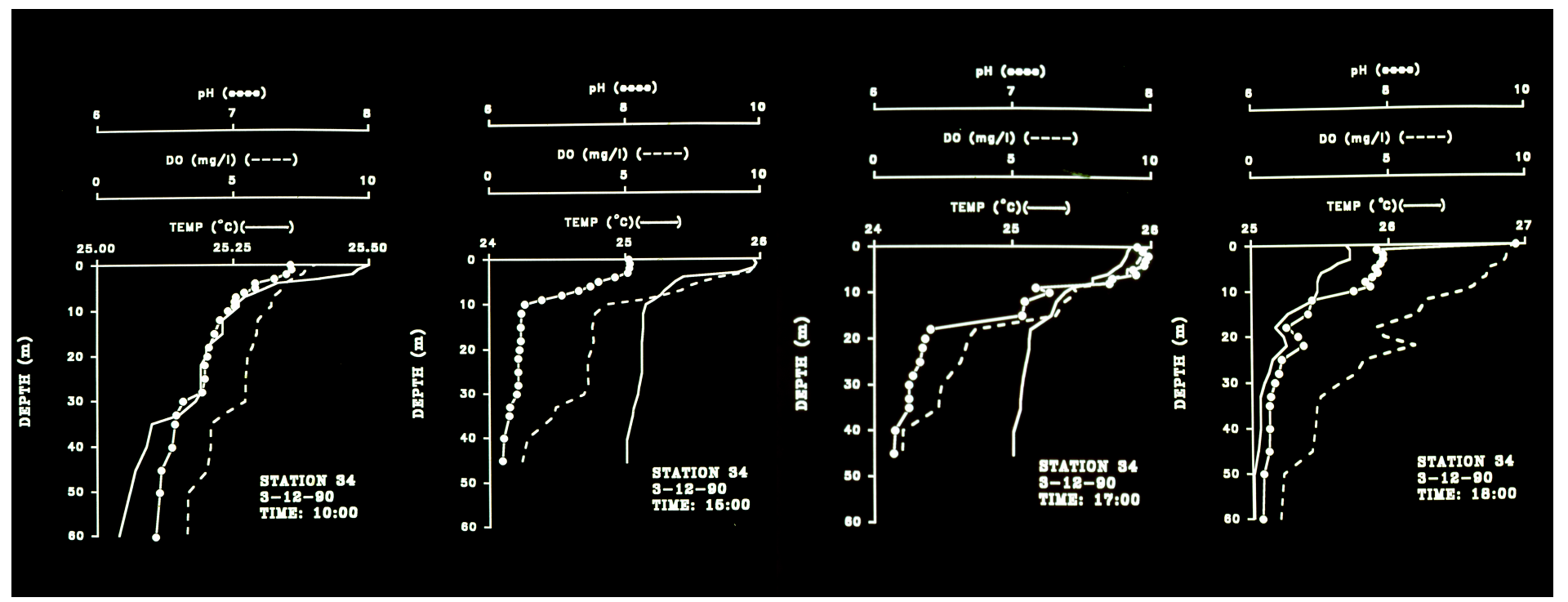

Figure 3: Temperature, $\mathrm{pH}$ and DO Profiles

Station 34, 3.12.90, 10:00 am-18:00 pm.

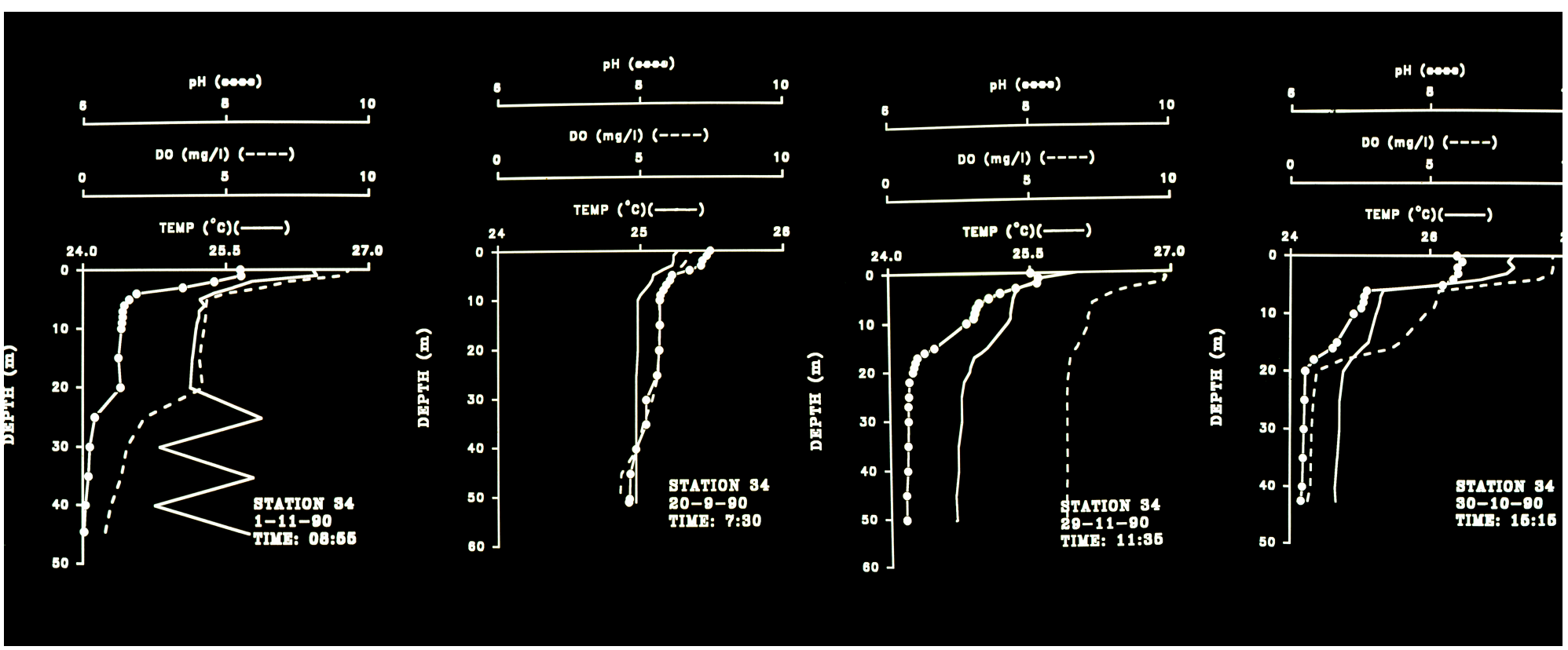

Figure 4: Temperature, $\mathrm{pH}$ and DO Profiles

Station 34, September-November 1990, 08:55 am-15:15 pm. 


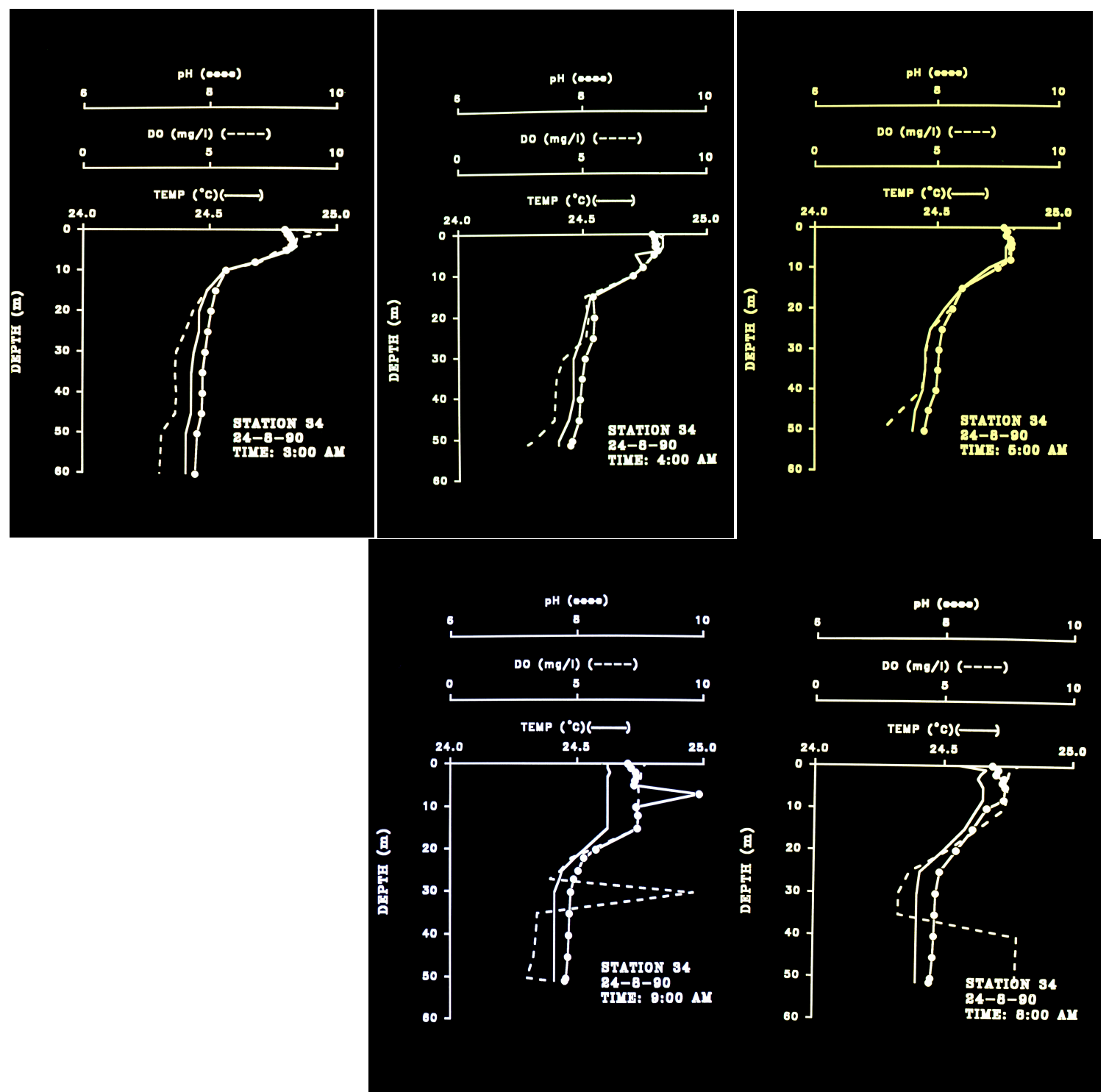

Figure 5: Temperature,

pH and DO Profiles Station 34, 24.8.90, 03:00 am-08:00 pm. 


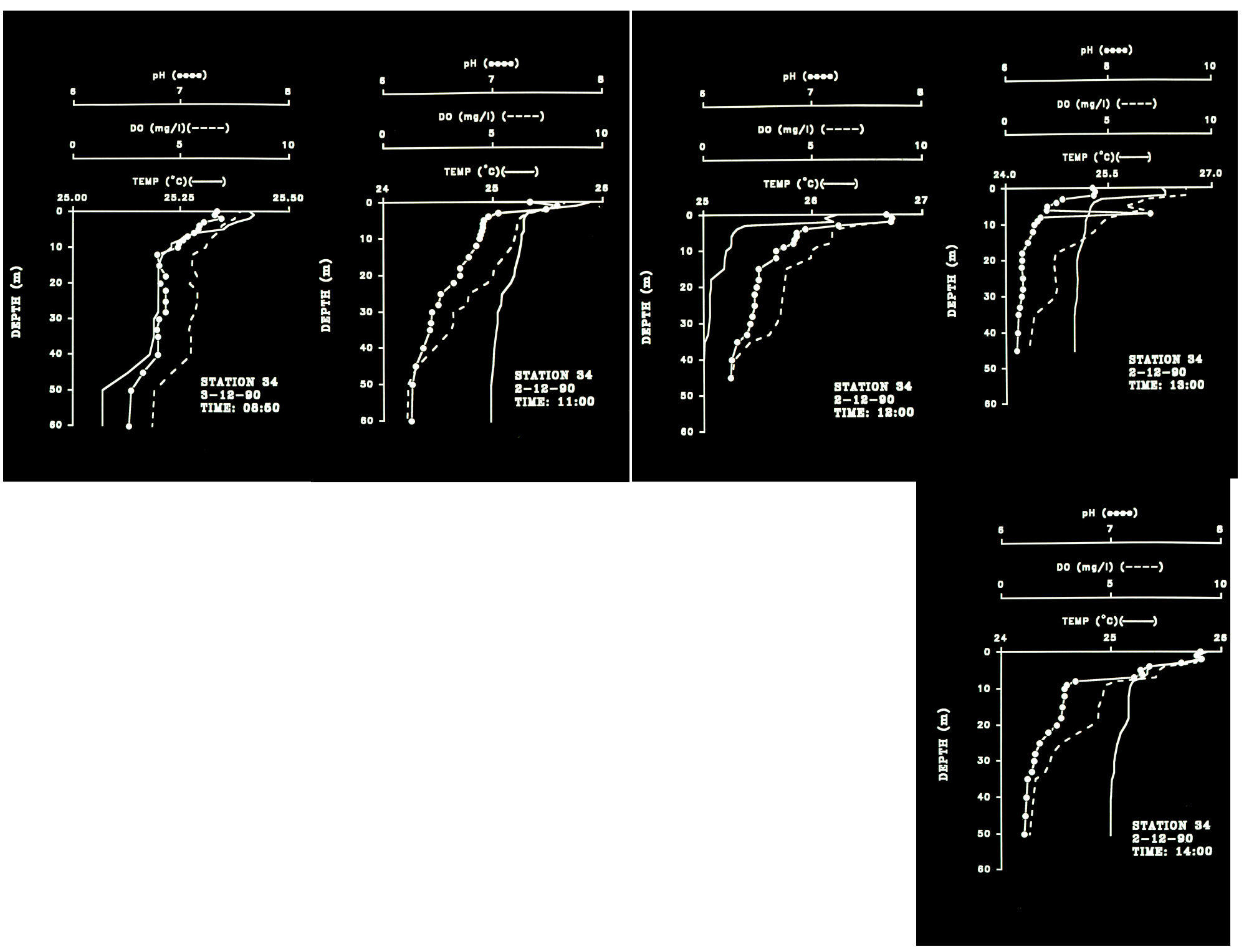

Figure 6 : Temperature, pH and DO Profiles Station 34, 2.12.90, 08:50am-14:00pm am-18:00 pm. 


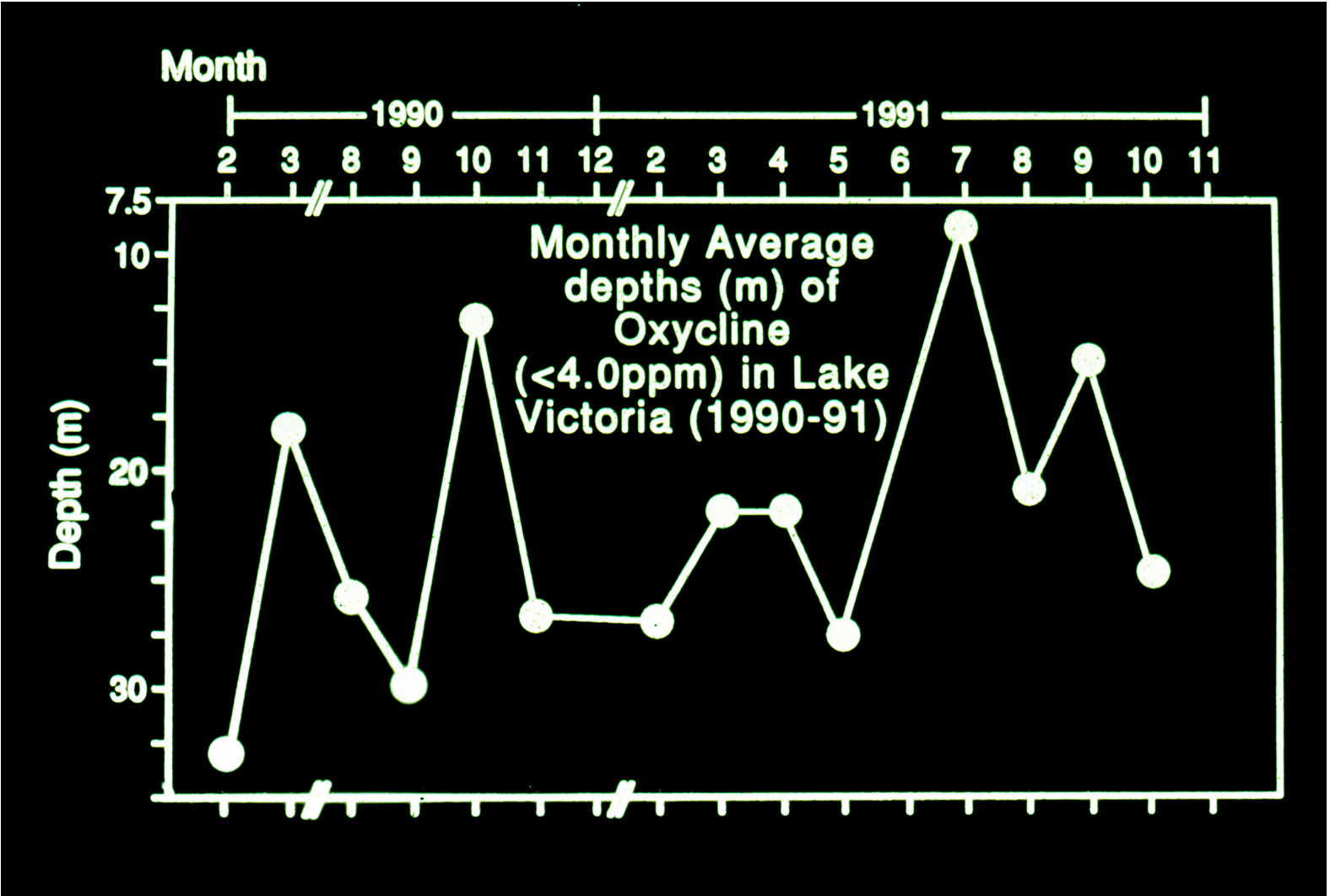

Figure 7: Monthly Average Depth (m) of Oxycline (<4 ppm D0) in Lake Victoria 1990-1991.

Lake Victoria - Kenya

Linear regression between $\mathrm{pH}$ and Temp. gradients (Max.-Min.) of monthly profiles in offshore stations (1990-91)

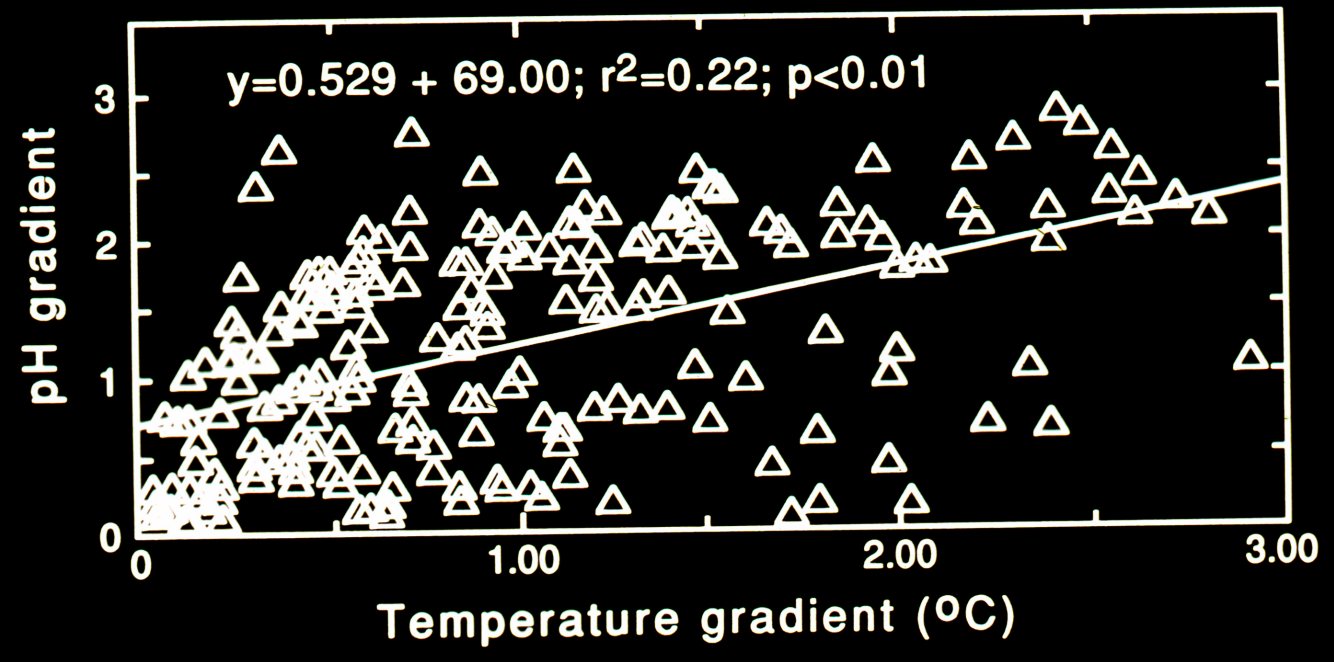

Figure 8: Linear Regressions ( $r^{2}$ and $p$ value are given) Between Thermal gradient (Max.-Min.) of monthly averages Profiles in offshore stations, Kenyan waters. 